UDC 378.147:811.124:004.738.5]:61-057.875

\author{
Ivanna I. Vorona \\ PhD in Philology, Associate Professor of the Department of Foreign Languages \\ Horbachevsky Ternopil State Medical University, Ternopil, Ukraine \\ ORCID ID 0000-0002-4038-5836 \\ voronaiv@ukr.net
}

\title{
INTERNET RESOURCES FOR THE COURSE OF LATIN IN MEDICAL UNIVERSITIES
}

\begin{abstract}
The features of using the Internet as a learning resource are described in the research. The necessity of using new educational technologies in the educational process because of the development of information and communication technologies is substantiated. The expediency of using the Internet resources of different purpose and complexity for learning Latin language as well as the list of websites is presented. The Internet Information Network offers a huge number of learning and informative materials different in form and content that greatly enhances students' interest in learning Latin and medical terminology as well as their opportunities to find, study and master the material. Much attention is paid to the use of the Internet by the rising experts in medicine during their independent study of the Latin language. The web resources of the Internet provide access to a wide range of achievements of world science and technology. This is evidenced by a large number of electronic resources of learning, reference, illustrative, game-like and literature content that can affect personal development, education and competence of the students. The access to new information materials is a powerful source of complementation of the theoretical and intellectual component of Latin learning. Using Internet information resources, wisely integrating them into the learning process, makes it possible to cope with a range of both didactic and social as well as cultural tasks more effectively: development of reading skills by using the materials of the network of different degrees of complexity; improvement of writing skills; increase of vocabulary with professional Latin terms; studying history of medical terms, their etymology. As a result of the study the conclusion has been drawn that the Internet with a variety of information and resources has a positive effect on the effectiveness of teaching the Latin language along with the development of motivation and interest of the students. The purposeful and competent use of the Internet resources in teaching Latin significantly improves the efficiency of the learning process and facilitates the study of vocabulary and grammar.
\end{abstract}

Keywords: Internet; Internet resources; information technologies; the Latin language; medical terminology.

\section{INTRODUCTION}

Target setting. Foreign and domestic policy of Ukraine, its strategic course towards joining the European and world community set new goals and objectives in higher education. The search for new technologies and techniques that allow students to learn terminology with the use of electronic resources is among such tasks.

Now everyone understands that the Internet provides great information opportunities. The Internet in the education system stimulates motivation for learning, expands the zone of individual activity of each student, and speeds up presentation of high-quality material. Internet technologies are an integral part of the general informational culture of a teacher and a student. However, it is important to distinguish which didactic goals current Internet technologies can target, how they can help to enrich and diversify the learning process. 
The trends in the implementation of information and communication technologies in higher medical education have significantly expanded the opportunities of studying the Latin language, have disclosed huge resources of electronic libraries, have promoted a more active use of scientific and educational potential as well as the experience of teaching Latin accumulated in the leading world universities.

Nowadays the effective methods of professional language teaching of medical students are being searched, as Latin is an instrumental and conceptual basis for the key subjects (anatomy, histology, pharmacology), which establish a basis for further conscious awareness of international medical terminology in the native language and modern foreign languages.

The Internet resources are particularly promising for learning Latin as well as for encouraging the students to improve their knowledge of Latin medical terminology. The problem resides in the fact that modern students sometimes do not have sufficient motivation for study and the task of the teacher is to show them that the process of learning a language can be easy and fun using modern technology. The use of Internet resources can be the source of fresh ideas in learning Latin.

The analysis of the latest literature. The issues of informatization of education as well as introduction of information technologies and electronic learning resources into the educational process of the universities in Ukraine are presented in the works of A. Hurzhii, Yu. Zhuk, P. Hurevych, O. Ivanytskyi, L. Kartashova, M. Koziar, V. Kukharenko, A. Mahamedov, S. Medvetskyi, V. Monakhov, S. Semerikov, V. Sergiienko, O. Spirin, V. Sumskyi, S. Rakov, O. Polischuk, I. Teplytskyi, S. Tkachenko, V. Yahupov and others. The importance of the Internet, websites and online courses in the study of foreign languages has been investigated in the works of Z. Berge, G. Dudeney, L. Van Lier, J. Magoto, L. Uzun, A-P. Lian [1-6]. The use of information technologies in learning Latin is presented in the articles of D. Drozdova [7]. In the research of O. Balalaieva the present development of electronic educational content in the Latin language has been studied and the attempts to systematize information on current foreign and domestic electronic resources and publications on study of Latin have been made [8].

Unresolved aspects of the problem. Despite a significant number of researches and many fruitful ideas and technologies suggested in scientific works, the issue of introduction of Internet resources to facilitate the learning of Latin and professional terminology by medical students has not been sufficiently studied.

The aim of the article is to define the didactic capabilities of Internet resources in teaching of the Latin language at medical universities; to study the peculiar features of the Internet resources usage in studying Latin; to analyse the websites that were offered to students for studying the Latin language and to describe the benefits of specific services.

\section{RESEARCH RESULTS}

\subsection{Internet Technologies in Learning Experiences}

Didactics establishes the education system as a fairly stable, open system. Its stability consists in the unchanging main didactic components, i.e. the purpose and content of study in accordance with accepted programs and standards of education. Variation is about the methods, organizational forms and means of learning [5]. Taking into account that the range of traditional educational tasks is expanding due to the focus on improving the quality of specialists' training, the use of Internet resources in teaching Latin is one of the ways of solving current didactic tasks. 
The work with Internet sources contributes to the integration of students' learning and research activities. The widespread use of videos and presentations enables the effective implementation of many didactic rules, in particular the fundamental principle of visualization [2].

The development and implementation of Internet technologies into the learning process updates the environments for arrangement of students' learning and teachers' pedagogical work, contributing to the expansion of opportunities for achievement of educational goals [9]. Web search is an important skill of any user and is ever more significant today. The Internet is a technological discovery that increases the amount and variety of information available to an individual, it expands the opportunities and scope of implementation of social communication providing the users with a comprehensive and quick access to various information sources [10].

The use of educational and informational websites, the possibility to read original texts, participate in various contests and competitions, watch educational video films, video clips facilitate an easy successful learning. It should be noted that these days the Internet for the students is a substitute of a traditional paper book, since in practical classes the students can work with electronic textbooks and manuals. The students can find in the network and download to a personal computer a large number of books; reading from the screen, they can study and adopt the material. It is easier for them to find a necessary passage, save material, process information [11].

\subsection{Internet Resources in Studying Latin}

A survey of the 180 first-year students of Ternopil State Medical University was conducted in order to find out their attitude to the study of the Latin language. It turned out that the needs of the students were very different, and sometimes it was difficult to combine them. The students hoped to improve reading, writing skills, vocabulary, and grammar. Another aspect, the students stressed, was the possibility to study professional terminology that would help them to deepen their knowledge of special disciplines. There were also those who wanted to master an advanced level of the language in order to engage in scientific research, to study the etymology of Latin medical terms and the influence of the Latin language on the English medical terminology. According to N. Katsman, the Latin language develops students' abstract thinking and scientific attitude to the study of terminology in any field of knowledge [12, p. 7]. Thus, taking into account such a wide spectrum of students' needs, the teacher should carefully and thoughtfully choose the course content, teaching materials, methods of work to motivate the students to work independently advising them effective ways of finding the right information.

Integration of Internet technologies into modern education and their use in teaching Latin are crucial issues. Many goals and objectives of the teaching and learning process are achieved using the Internet as a means of teaching Latin. Learning goals include mastering knowledge, skills and expertise; developmental goals - development of intellectual, emotional and volitional, behavioural sphere of personality; educational goals - development of a scientific worldview, moral, artistic and aesthetic culture, etc.

With the support of the European Commission in 2006, the Classics and ICT Resource Course for Europe (CIRCE) project has been launched and has combined the efforts of European scholars and teachers in the development of effective methods of information and communication technologies use in teaching classical languages. The aim of the project is to support and provide the teachers with effective methods of using computer technology in the learning process. According to this project, methodological recommendations for teachers were published, in which the authors noted that traditional methods of teaching Latin and Ancient 
Greek should be revised in the $21^{\text {st }}$ century. Theoretical and practical advice on how to use the existing and develop new electronic resources for learning Latin can be found there, as well as research results on this matter [13].

The information resources of the Internet in the study of the Latin language, logically integrated into the learning process, make it possible to solve a range of both didactic and sociocultural tasks: development of reading skills by using the materials of the network of different complexity; improvement of grammar in the use of Latin medical terms; development of writing skills; development of vocabulary; getting acquainted with the culture of Ancient Rome and Ancient Greece, its influence on the formation of medical terms; development of students' creativity, their creative initiative; increase in the students' motivation for independent work; choosing the possibilities of individualization and differentiation of students' work; creating a positive psychological atmosphere during students' independent work.

There are two ways to use Internet resources when learning Latin. The first one is the use of the Internet as a structural element of the class. During the class, the educational situations are created by using the electronic resources: watching videos or films, doing online tests, tasks for development of lexical, grammatical and phonetic skills. The second way is the use of the Internet for students' independent work; it is a very effective means of using the Internet for educational purposes. It consists of preparation of homework in the form of presentations, search and choosing of videos or interesting information on the suggested topics, preparation of projects. The tasks may be individual (for each student) or general. Of course, it is difficult for a student to navigate in the information flow on their own; that is why the teacher should provide methodological advice to the student on how to study on their own, highlight the main educational websites, which the students will work with in non-school hours. Usually this is a list of Internet sources and educational databases for learning Latin. For effective organization of learning by means of educational websites a teacher should focus the search activity of the students, help them to get their bearings in the flow of information, assist with certain tasks. Use of electronic resources allows the most complete realization of the principle of person-centred education [14].

The principle of individualization in a computerized process of learning Latin is provided by the possibility of choosing individual time of work, individual management of learning, using the tasks of different complexity with the possibility to move to the more complex ones, or using the options of the program depending on the learning outcomes.

\subsection{Analysis of the websites for studying the Latin language}

The latest tendencies of information and communication technologies implementation into education have significantly expanded the possibilities of studying Latin, disclosed resources of world libraries, and allowed more active use of scientific and educational potential as well as the gathered Latin teaching experience of the world leading universities.

In the beginning of 2017-2018, the first-year students of the Faculties of Medicine, Dentistry and Pharmacy of Ternopil State Medical University were offered to use some websites to learn Latin extra. According to the analysis of students' questionnaires and study of teachers' pedagogical activity, the most popular Internet websites designed for the study of Latin and the culture of antiquity were defined. The websites can be divided into informational and training. The informational websites are used to search for interesting information, creative tasks, and supplementary material. Special educational websites contain tasks and exercises for development of various educational skills. 
Most of Internet resources are presented in English and this may cause some inconvenience for Ukrainian audience. Also the differences in pronunciation of Latin sounds used in the European and Slavic learning traditions should be taken into account. Since a large number of students from different countries of the world study at our university and all disciplines are taught in English, the international students were also offered to use English-language informational and educational websites for learning the Latin language. The English-speaking students successfully used information of the Internet resources, which resulted in their significantly higher language proficiency. One of the international students who used the offered websites most became a prize-winner in the National Olympiad in Latin in Poltava, Ukraine.

The great resource of the written heritage of the past is presented in the electronic library of the ancient and biblical literature Musaios (http://www.musaios.com), which offers two databases: TLG (Thesaurus Linguae Graecae) and PHI5 (Latin Texts and Bible Versions). Original Latin texts (essays, stories, poems, plays and other works) are presented on the website The Latin Library (http://www.thelatinlibrary.com).

Perseus Digital Library (http://www.perseus.tufts.edu/hopper/), which has the largest database of Latin and Greek materials comprising original texts and their translations, graphic objects, is one of the best electronic libraries. The Perseus Digital project was initiated in 1987 to collect and submit materials to study ancient Greece. Two CD-ROMs were published and the Perseus Digital Library was created in 1995. The digital collection contains about 4 million text materials, over 64 thousand images and presentations, but the most significant feature of the library is the efficient allocation of materials and a comprehensive database.

The Digital Library Corpus Scriptorum Latinorum (http://www.forumromanum.org/literature/) is a part of the Forum Romanum project, containing a large number of Latin sources: from the most ancient written records to the works of the $18^{\text {th }}$ century. This is a convenient search engine, where one can find a work by author, title, year, genre.

In addition to information resources designed for those already familiar with the basics of Latin, the users are also offered a variety of courses to study this language.

Cambridge Latin Course (https://www.cambridgescp.com) has been one of the best Latin courses for beginners for over 45 years. This course, in addition to the existing traditional printed edition, is now available in DVD and online formats to enhance standards. For a better study of Latin and ensuring wider access to this discipline, a Cambridge Latin Course E-Learning Resources project approved by the British government was created. The course consists of two editions that contain text, video and audio materials [15].

The interactive course Latinum Electronicum (http://www.latinum.moutoncontent.com/\#data/learn/de/01/00/g1_0.html) for studying the basics of Latin was developed by Irene Burch, Simone Hiltscher, Rudolf Wachter in 2008 as part of Virtual Campus project, which aims to create training courses for distance learning by active use of information technology in higher education. The course is presented in three languages: German, French, Italian; it is divided into 23 classes and assists in preparing for the examination in Latin. There are more than 400 exercises of diverse complexity; a dictionary; word cards that may be printed, and original texts with translation.

The Rosetta Stone: Latin (https://www.rosettastone.com/learn-latin/) multimedia course was developed to study Latin from zero level (3 levels of complexity are offered) [16]. The methodology of a combination of text, image and sound is used so that the user can memorize the words, by means of which phrases and sentences are formed in a systematic progression. In classes the following kinds of speech activity are used: listening, reading, speaking; interactive 
exercises are offered. Such a methodology involves learning the language by immersion in the linguistic environment, multiple repetitions and formation of associative series on different topics. Of course, such an approach is more appropriate in the study of living languages.

When learning Latin the development of skills and expertise in declension, determination of the type of syntactic structure, translation is very important. Some students need more repetitions and self-assessments to perform these activities correctly than the teacher can provide in classroom. The resources presented on the Internet contain tests and exercises in Latin of different complexity for checking grammar and translation skills. Oxford Latin Course: Online (https://www.conted.ox.ac.uk/about/latin-language-courses) online course is designed to help students learn Latin. The inventors of the course emphasize that text reading with comprehension questions and model answers to them are not the main ways of learning Latin. The students still need to practice words declension. An easy way to make Latin forms and get an immediate result is offered for the students. A book Internet Workbook for the Oxford Latin Course (http://artemis.austincollege.edu/acad/cml/rcape/latin/) is an addition to the course with grammar tasks in Latin.

The Ephemeris (http://ephemeris.alcuinus.net/index.php) website contains an electronic version of newspapers and magazines in Latin. This resource is useful for a better understanding of Latin, because, while reading news on different topics, a student learns new vocabulary better. Medical students would be interested in review of Valetudo \& Medicina (http://ephemeris.alcuinus.net/medicina.php) journal for learning professional medical terminology.

There are much fewer Russian and Ukrainian websites for learners of Latin on the Internet. Thus, the website of the Department of Classical Philology of Belarusian State University "Philologia classica" (http://graecolatini.bsu.by/index.html) offers 12 textbooks and manuals in PDF and DV format for the students of philological, historical, philosophical, medical, law specialties, as well as educational and methodological complex for off-campus students to study Latin. The website contains I. Dvoretskyi Latin-Russian Dictionary and K. Tananushko electronic Latin-Russian Dictionary, a version of which is used by ABBYY Lingvo 12 ML. $\mathrm{K}$. Tananushko Dictionary is the first lexicographic research which presents the development of Latin vocabulary - it includes vocabulary of classical period of Latin, as well as recent terms of medical, pharmaceutical, biological nomenclature, which significantly expands the scope of its use. In addition, the resource offers a program converter that allows converting dates to Gregorian and Julian calendars; anthem "Gaudeamus", Christian prayers "Pater Noster", "Ave, Maria" (MP3, notes, text, translation).

The Russian-language website Lingua Latina (http://www.lingualatina.ru/) is aimed at studying Latin history and grammar. The main textbook and tests are provided, as well as keys to exercises for self-assessment.

The Lingua Latina Aeterna (http://linguaeterna.com/ua/) website is a page of living Latin and unites the enthusiasts of the revival of this language. The designers of the page consider that Latin can and must be of the same significance as in the recent past. The website contains interesting works in Latin that are little-known for general public, Latin-Russian dictionaries and phrasebooks, as well as various educational materials. A Latin-Russian Dictionary is being written; it contains the vocabulary of the Classical period as well as the Middle Ages, the Renaissance and the Modern Times including neologisms that define the concepts of the presentday reality. The issues of methodology of teaching Latin, the nuances of Latin writings translation, audio and video materials to study Latin, useful links to other resources are regularly discussed on the website forum. The website offers four language options: Latin, English, 
Russian and Ukrainian. There is little material in Ukrainian on the website: the books "Latin legal pithy sayings" and "The most common Latin legal terms and aphorisms". In the Classical Philology section the publications of Ukrainian scientists are listed.

The aim of the Medievist: Ukrainian Latin-language literature project (http://www.medievist.org.ua), which was initiated in 2009, is to combine the scientific works of modern authors, original Latin texts and translations. The website is a platform where scholars can share their own works and communicate with colleagues. The designers of the project intended to respect fundamental missions: informational (contribute to the deepening of knowledge of Ukrainian cultural and historical achievements as a complex and multicomponent phenomenon; provide information rather than impose their own views), innovative (generate new trends and create traditions: work on the development of economically feasible models of research in humanities, take advantage of the information age technologies, offer their views without rejecting the attainments of others) and scientific (simplify the work of a researcher by disclosing Latin-language early printed books and create their own intellectual product in NeoLatin; manage offline projects). The experts of the website also offer educational services: Latin courses, consultations on specific topics of grammar and syntax, as well as on terminology).

Ancient Greek or Latin and culture of Ancient Greece and Rome can be studied on the Ukrainian website Pinax (http://www.pinax.com.ua), which offers mainly the materials of Latin, Ancient Greek and Culture of Ancient Greece and Rome courses, which are taught to the students of Taras Shevchenko Kyiv National University by the teachers of the Department of General Linguistics and Classical Philology. The Latin course includes Latin pithy sayings, grammatical tables, grammatical analysis schemes, samples of tests, articles, the anthem "Gaudeamus" translated by Ukrainian poets and university students, and videos on the specialty "Classical Languages. Western European Language". The section "Latin Language and Medical Terminology", which contains presentations in English on Latin grammar and medical terms usage, is worth paying attention to.

In addition to numerous popular online resources for studying Latin, there are also courses developed for certain areas and specialties. As a rule, such resources are created by university teachers for off-campus or online students.

The aim of the Anatom (http://anatom.ua/) website is to provide a support to those who begin studying the human body structure, to enable the more experienced people to develop their skills and expertise, to motivate professionals to share their knowledge, taking into account the established traditions, advanced technologies and feedback. The initiators provide anatomical terminology, recommend compulsory literature, provide the students with the opportunity to assess their knowledge by taking interesting tests.

For learning new vocabulary, various electronic dictionaries and online translators are popular. The most popular electronic dictionary for translating from Latin into English and vice versa is William Whitakers WORDS (https://mk270.github.io/whitakers-words/index.html). It is important that the computer program (written in ADA) can analyse the changes in the form of words typical for Latin and translate the roots into English. A simple and user-friendly interface, a significant Latin vocabulary (about 39000 Latin words) and a correct translation make the dictionary even more popular.

Using the Blitz Latin (https://blitzlatin.com) Latin-English translator, users can automatically translate words as well as texts from Latin into English. For accuracy of translation it is possible to choose age (Classical or Medieval), sphere of usage (biological, medical, linguistic, legal), to review all alternative meanings of the word. Three additional modules are offered with the dictionary: HTMStrip provides text formatting; Inscript is a fast way to search 
the documents database of the University of Frankfurt; Counter - counts the amount of Latin words in the text, provides statistical analysis of words in the sentence and standard deviations.

The extremely rapid and powerful online dictionary The Latin Lexicon (https://latinlexicon.org) is created by means of AJAX technology; it has a user-friendly interface and a well thought-out navigation system. The program offers word translation as well as its inflectional paradigm and examples of use in the writings of classical authors.

On Vocabularium latinorussicum magnum website (http://linguaeterna.com/vocabula/) the electronic version of the printed I.H. Dvoretskyi Latin-Russian Dictionary is presented.

The Ukrainian-Latin online dictionary (https://glosbe.com) (8 260 phrases of LatinUkrainian direction of translation and 7765 vice versa) offers Latin-Ukrainian translation, possible phrases and examples of the use of a word in a sentence, and sound accompaniment to some words. Nevertheless, the presence of a macaronic Russian-English interface is negative, in particular the basic instructions are in Russian, and grammatical comments - in English, occasionally in Polish.

In addition to the dictionaries of common lexis, the users are also offered dictionaries of medical terminology. In particular, the Latin-Russian-Latin Anatomical Dictionary in the Polyglossum dictionary program preceded the printed publication. The authors of the dictionary set the goal to collect the maximum number of anatomical terms (about 30000) compulsory for medical students and doctors, as well as translators [17].

ABBYY Lingvo 12 ML contains only two Latin-Ukrainian dictionaries: special Ukrainian part of the seven-language "Lexicon Heptaglotton", reconstructed according to the text of V. Svoboda "Slavonic Part of Oxford Heptaglot: Ukrainian-Latin Dictionary of the first half of the $17^{\text {th }}$ century" and "Latin-Ukrainian/Ukrainian-Latin Dictionaries of Clinical and Pharmaceutical Terms", written according to the textbook "Latin: Formulation. Clinical terminology" [18]. No other Latin-Ukrainian electronic dictionaries have been found on the Internet.

Table 1. The main features of the analysed websites

\begin{tabular}{|l|c|c|c|c|c|c|}
\hline \multicolumn{1}{|c|}{ Website title } & $\begin{array}{c}\text { Presence } \\
\text { of source } \\
\text { texts }\end{array}$ & $\begin{array}{c}\text { Development } \\
\text { of lexical } \\
\text { competence }\end{array}$ & $\begin{array}{c}\text { Development } \\
\text { of grammatical } \\
\text { competence }\end{array}$ & $\begin{array}{c}\text { Presence } \\
\text { of } \\
\text { training } \\
\text { exercises }\end{array}$ & $\begin{array}{c}\text { Presence of } \\
\text { video and } \\
\text { audio } \\
\text { materials }\end{array}$ & $\begin{array}{c}\text { Language of } \\
\text { presentation }\end{array}$ \\
\hline Musaios & + & + & - & - & - & English \\
\hline $\begin{array}{l}\text { The Latin } \\
\text { Library }\end{array}$ & + & - & - & - & + & English \\
\hline $\begin{array}{l}\text { Corpus } \\
\text { Scriptorum } \\
\text { Latinorum }\end{array}$ & + & - & - & - & - & English \\
\hline $\begin{array}{l}\text { Cambridge } \\
\text { Latin Course }\end{array}$ & + & + & + & + & + & English \\
\hline $\begin{array}{l}\text { Latinum } \\
\text { Electronicum }\end{array}$ & - & + & + & + & + & $\begin{array}{c}\text { German, } \\
\text { French, } \\
\text { Italian }\end{array}$ \\
\hline & & & & + & & $\begin{array}{c}\text { English, } \\
\text { German, } \\
\text { French, } \\
\text { Italian, } \\
\text { Rosetta Stone }\end{array}$ \\
\hline & - & + & + & + & & \\
\hline
\end{tabular}




\begin{tabular}{|c|c|c|c|c|c|c|}
\hline $\begin{array}{l}\text { Oxford Latin } \\
\text { Course: Online }\end{array}$ & - & + & + & + & - & English \\
\hline Ephemeris & + & + & - & - & - & English \\
\hline $\begin{array}{l}\text { Philologia } \\
\text { classica }\end{array}$ & - & + & + & + & - & Russian \\
\hline Lingua Latina & - & + & + & + & - & Russian \\
\hline $\begin{array}{l}\text { Lingua Latina } \\
\text { Aeterna }\end{array}$ & - & + & + & + & + & $\begin{array}{l}\text { English, } \\
\text { Russian, } \\
\text { Ukrainian }\end{array}$ \\
\hline $\begin{array}{l}\text { Medievist: } \\
\text { Ukrainian } \\
\text { Latin-language } \\
\text { literature }\end{array}$ & + & - & + & - & - & Ukrainian \\
\hline Pinax & - & + & + & + & + & Ukrainian \\
\hline Anatom & - & + & - & + & + & Ukrainian \\
\hline
\end{tabular}

The international students, for whom teaching is provided in English, actively use the online dictionaries William Whitakers WORDS and Blitz Latin, while the Ukrainian students Vocabularium latinorussicum magnum and $A B B Y Y$ Lingvo $12 \mathrm{ML}$ for translation of single words or phrases.

The use of Internet resources in teaching Latin allows developing a unique learning environment in which, on the one hand, the activity of each student in the process of learning is stimulated, on the other hand, the situations for the students' group activity are created, their creative initiative as well as individual and personal characteristics are developed. The use of Internet resources facilitated the involvement of the students of the Department of Foreign Languages of Ternopil State Medical University in the research, the development of their skills of orientation in a huge informational space as well as their independent decision-making.

\section{CONCLUSIONS AND PROSPECTS FOR FURTHER RESEARCH}

In the process of active use of electronic resources in studying Latin, the student is able to develop speech skills and study professional terminology. The use of new information technologies allows improving the efficiency of education as well as facilitating further independent study of Latin by the students.

The Internet network for learning Latin is an effective means of studying the fundamentals of grammar and professional terminology for medical students. By satiating the students' natural curiosity in finding information and working online, we provide them with the environments for effective study of the Latin language. The use of new information technologies provides individualization and differentiation of learning, taking into account the students' abilities, their inclinations, enriches their social and cultural competence, removes psychological barrier to learning languages, develops social and personal qualities of the students, their self-confidence.

Taking into account the student surveys, the conclusion has been drawn that the interactive courses for studying the fundamentals of Latin (Latinum Electronicum, Rosetta Stone: Latin, Oxford Latin Course) are the most popular. Also, the websites used by the students to study the culture of Ancient Greece and Rome (Perseus Digital Library, Pinax), as well as various dictionaries and online translators (William Whitakers WORDS, Blitz Latin, The Ukrainian-Latin 
online dictionary) were very informative. To study anatomical and clinical terminology, the students most often chose the educational website Anatom. It has been established that the English-language websites are of great interest to the international students; they used them not only to learn the Latin language, but also to create their own presentations and to prepare projects. Therefore, the use of Internet resources in the process of learning the Latin language is a powerful source of information, a means of individualization of learning, evaluation and assessment of knowledge, as well as a means for stimulating students' creative initiative and their encouragement to study.

The analysis of research and methodological approaches to the use of virtual learning environment in studying the Latin language and medical terminology by the students of medical universities, as well as the generalization of the experience of virtual curriculum use in the study of Latin grammar at the Department of Foreign Languages of Ternopil State Medical University are the prospects of further scientific research.

\section{REFERENCES (TRANSLATED AND TRANSLITERATED)}

[1] Z. Berge, M. Collins, Computer-mediated communication and the online classroom in distance learning. Cresskill, NJ: Hampton Press. 1995. (in English)

[2] G. Dudeney, N. Hockly, How to teach English with technology. Harlow : Pearson Education Limited, 2007. 192 p. (in English)

[3] A-P. Lian, Reflections on language-learning in the 21st century: The rhizome at work. Rangsit Journal of Arts and Sciences, 1. 2011. P. 5-17. (in English)

[4] L. van Lier, Internet and language education. Encyclopedia of Language \& Linguistics (2nd ed.). 2006. P. 758-764. http://dx.doi.org/10.1016/B0-08-044854-2/00674-X (in English)

[5] J. Magoto, From the nets: World Wide Web and ESL. CAELL Journal. 1995. Vol. 5. № 4. P. 21-26. (in English)

[6] L. Uzun, The Internet and computer-mediated artefacts for foreign language learning and practice, and intercultural communication: MOODLE, Second Life, and Others. Procedia - Social and Behavioral Sciences, 46. 2012, P. 3296 - 3300. (in English)

[7] D. V. Drozdova, Electronic educational resource for online support of teaching Latin in the text of N.L. Katsman, Online virtual learning. M.: SGU, 2011. № 3(45). P. 4-12. (in Russian)

[8] O. Yu. Balalaieva, Analytical review of electronic resources for Latin study, Information technologies and training resources. 2014. Issue. 2 (40). P. 74-82. (in Ukrainian)

[9] P.M. Bisirkin, Facilities of ICT of learning in the educational process of technical training institutions, Information technologies and training resources. Kyiv, IITLT NAES of Ukraine. 2008. V. 4 (8). [Online]. Available: http://lib.iitta.gov.ua/id/eprint/298. (in Ukrainian)

[10] I.V. Pyholenko, Internet technologies as a means of value orientations development of the students towards the information society (for example, NTUU KPI), extended abstract of dissertation for PhD. Kyiv, 2007. 20 p. (in Ukrainian)

[11] Yu. A. Briskin, Branch features of Internet education, Computer in the school and family. 2004. No.1. P. 1517. (in Ukrainian)

[12] N. L. Katsman, Methodology of Latin teaching in the universities and foreign language faculties. Moscow: Vysshaia shkola, 1979, 142 p. (in Russian)

[13] V. de Troyer, M. de Biasi, R. Delisle [et al.] A Classics \& ICT resource course for Europe: a manual for teachers of classical subjects in secondary schools throughout Europe. CIRCE Project, 2006. 123 p. (in English)

[14] O. Tokmenko, Information technologies in teaching foreign languages: today and down the ages, Foreign languages in schools. 2006. No. 2. P. 98-100. (in Ukrainian)

[15] Cambridge Latin Course. Book I: E-Learning Resource [electronic resource] / by Cambridge School Classics Project. Cambridge University Press, 2007. 1 DVD-ROM. Title of the screen. (in English)

[16] Rosetta Stone, Latin (levels 1-3, ver. 3) [electronic resource]: multimedia course. 2011. 1 DVD-ROM. Title of the screen. (in English) 
[17] S. Kozhubeev, O. Smirnitskiy, Latin-Russian-Latin Anatomical Dictionary Polyglossum 3.7. Moscow, 2011. [Online]. Available: http://www.ets.ru. (in Russian)

[18] G. O. Krakoveczka, V. M. Bobyrov, O. M. Byelyayeva, Latin. Recipe. Clinical terminology: a textbook for medical universities. Kyiv: Zdorovia, 1999. 356 p. (in Ukrainian)

Text of the article was accepted by Editorial Team 21.11.2018

\title{
ВИКОРИСТАННЯ ІНТЕРНЕТ-РЕСУРСІВ ДЛЯ ВИВЧЕННЯ ЛАТИНСЬКОЇ МОВИ В МЕДИЧНИХ УНІВЕРСИТЕТАХ
}

\author{
Ворона Іванна Іванівна \\ кандидат філологічних наук, доцент кафедри іноземних мов \\ ДВНЗ «Тернопільський державний медичний університет ім. І. Я. Горбачевського МОЗ України», \\ м. Тернопіль, Україна \\ ORCID ID 0000-0002-9118-9456 \\ voronaiv@ukr.net
}

\begin{abstract}
Анотація. У розвідці розглянуто особливості використання мережі Інтернет як освітнього ресурсу. Вказано на необхідність використання нових освітніх технологій у навчальному процесі у зв'язку з розвитком інформаційно-комунікаційних технологій. Розкрито доцільність використання різноманітних за призначенням та рівнем складності ресурсів мережі Інтернет для вивчення латинської мови, подано перелік сайтів. Інформаційна мережа Інтернет пропонує значну кількість навчальних і пізнавальних матеріалів, різних за формами і змістом, чим значно підвищує зацікавленість студентів до вивчення латинської мови та медичної термінології, розширює можливості студентів знаходити, вивчати і засвоювати матеріал. Звернено увагу на використання Інтернету майбутніми фахівцями сфери медицини під час самостійного вивчення латинської мови. Використання вебресурсів Інтернет-мережі надає можливості доступу до широкого спектру досягнень світової науки та технологій. Про це свідчить наявність великої кількості електронних ресурсів начального, довідкового, ілюстративного, ігрового та літературного контенту, який може впливати на загальний розвиток, освіту та компетентність студентів. Доступ до нових інформаційних матеріалів $\epsilon$ потужним джерелом доповнення теоретичної та інтелектуальної складової вивчення латинської мови. Використовуючи інформаційні ресурси мережі Інтернет, розумно інтегруючи їх у навчальний процес, можна більш ефективно вирішувати цілий ряд як дидактичних, так і соціокультурних завдань: формування навичок читання, безпосередньо використовуючи матеріали мережі різного ступеня складності; удосконалення навичок письмової мови; поповнення свого словникового запасу фаховою лексикою латинської мови; вивчення історії виникнення медичних термінів, їх етимології. Результатом проведеного дослідження є висновок про те, що використання мережі Інтернет з різноманіттям інформації і ресурсів у цілому позитивно впливає на ефективність вивчення латинської мови разом із розвитком мотивації й інтересу самих студентів. Цілеспрямоване й кваліфіковане застосування Інтернет-ресурсів у навчанні латинської мови значно підвищує ефективність навчального процесу i забезпечує вивчення лексики та граматики.
\end{abstract}

Ключові слова: Інтернет; Інтернет-ресурси; інформаційні технології; латинська мова; медична термінологія. 


\title{
ИСПОЛЬЗОВАНИЕ ИНТЕРНЕТ-РЕСУРСОВ ДЛЯ ИЗУЧЕНИЯ ЛАТИНСКОГО ЯЗЫКА В МЕДИЦИНСКИХ УНИВЕРСИТЕТАХ
}

\section{Ворона Иванна Ивановна}

кандидат филологических наук, доцент кафедры иностранных языков

ГВУЗ «Тернопольский государственный медицинский университет им. И. Я. Горбачевского МОЗ Украины», г. Тернополь, Украина

ORCID ID 0000-0002-9118-9456

voronaiv@ukr.net

\begin{abstract}
Аннотация. В статье рассмотрены особенности использования сети Интернет как образовательного ресурса. Указано на необходимость использования новых образовательных технологий в учебном процессе в связи с развитием информационно-коммуникационных технологий. Раскрыто целесообразность использования различных по назначению и уровню сложности ресурсов сети Интернет для изучения латинского языка, перечислены сайты. Информационная сеть Интернет предлагает значительное количество учебных и познавательных материалов, разных по формам и содержанию, чем значительно повышает заинтересованность студентов в изучении латинского языка и медицинской терминологии, расширяет возможности студентов находить, изучать и осваивать материал. Обращено внимание на использование Интернета будущими специалистами сферы медицины с помощью самостоятельного изучения латинского языка. Использование веб-ресурсов Интернет-сети, предоставляет возможности доступа к широкому спектру достижений мировой науки и технологий. Об этом свидетельствует наличие большого количества электронных ресурсов учебного, справочного, иллюстративного, игрового и литературного контента, который может влиять на общее развитие, образование и компетентность студентов. Доступ к новым информационным материалам является мощным источником дополнения к теоретической и интеллектуальной составляющей изучения латинского языка. Используя информационные ресурсы сети Интернет, интегрируя их в учебный процесс, можно более эффективно решать целый ряд как дидактических, так и социокультурных задач: формирование навыков чтения, непосредственно используя материалы сети разной степени сложности; совершенствование навыков письменной речи; пополнение своего словарного запаса профессиональной лексикой латинского языка; изучение истории возникновения медицинских терминов, их этимологии. Результатом проведенного исследования является вывод о том, что использование сети Интернет с многообразием информации и ресурсов в целом положительно влияет на эффективность обучения латинскому языку, вместе с развитием мотивации и интереса самих студентов. Целенаправленное и квалифицированное применение Интернет-ресурсов для обучения латинскому языку значительно повышает эффективность учебного процесса и обеспечивает изучение лексики и грамматики.
\end{abstract}

Ключевые слова: Интернет; Интернет-ресурсы; информационные технологии; латинский язык; медицинская терминология.

\section{(CC) EY-NC-SA}

This work is licensed under Creative Commons Attribution-NonCommercial-ShareAlike 4.0 International License. 